\title{
"Investors are good, if they follow the rules" - power relations and local perceptions in the case of two European forestry companies in Tanzania
}

\author{
M. Locher and U. Müller-Böker \\ Human Geography, Department of Geography, University of Zurich, Zurich, Switzerland \\ Correspondence to: M. Locher (martina.locher@geo.uzh.ch)
}

Received: 30 April 2013 - Revised: 14 January 2014 - Accepted: 21 January 2014 - Published: 11 December 2014

\begin{abstract}
The rapidly increasing interest of foreign investors in land in the global South, also termed land grabbing, has been widely discussed as potentially supportive, but often rather harmful for local populations. Combining a critical livelihoods perspective with access theory and a bargaining model, this study scrutinizes local people's perceptions of the land investments, power relations during land negotiations and intra-community differences. By analysing two European forestry companies in Tanzania, we have chosen a sector and a country with presumably more positive outcomes for local populations. The deals resulted in not only labour opportunities and infrastructural improvements, which are mainly perceived as positive, but also cases of violated land rights, inadequate compensation and decreased food security. Hence, even under favourable preconditions, the consequences for local people are ambivalent. With this study, we contribute to a differentiated analysis of the contested role of large-scale land deals in contemporary rural development.
\end{abstract}

\section{Introduction}

The rapidly increasing interest of foreign investors in land in the global South is a prominent phenomenon of new rural dynamics, often termed global land rush or land grabbing. Large-scale land acquisitions, mostly in the form of longterm leases of land, aim mainly at food and biofuels production for export as well as at speculation. They are related to drivers such as the financial and food markets and climate policies (Peters, 2013). Transnational land acquisitions have been widely discussed as potentially supportive, but often rather harmful for local populations, particularly smallholders. Concerns include violated land rights and lack of access to land-based natural resources for local people, resulting in decreased food security and ultimately the replacement of smallholders by badly paid labourers and unemployed landless poor (Cotula et al., 2009; de Schutter, 2011; Li, 2011). Yet, land deals should be portrayed neither as simply "providing much-needed capital and technology for third world agricultural production, food security and employment" nor as "neo-colonial scrambles for land and resources conducted by predatory investors at the expense of marginal popula- tions abroad" (Wolford et al., 2013:191-192). Instead, more in-depth case studies are needed that provide a nuanced analysis of the interaction of the involved stakeholders and bring in local views (Smalley and Corbera, 2012; Edelman et al., 2013).

This article aims to contribute to this debate with insights from two case studies of forestry projects in Tanzania. We argue that it is particularly crucial to look at how land deals are negotiated. Power relations between investors and local people are usually unbalanced in favour of investors (Borras Jr. and Franco, 2012:54). However, there are also cases where local people have considerably influenced investment projects (Smalley and Corbera, 2012). By employing access theory and a bargaining perspective, we contribute to a more specific understanding of the balance of powers in the negotiation process. Further, we present the local people's views, and consider their heterogeneity in the power analysis. Hence, we address the observation of Evers et al. (2013:4) that "... the sentiments of the 'local population' are hardly homogeneous and often absent from the debates".

We have chosen the case studies deliberately with the aim of analysing large-scale land acquisitions with potentially 
positive consequences. By looking at these cases we add to a more complete picture of the global land rush. While much of the literature on the land rush examined land deals related to food or biofuels production, less attention has been paid to forestry plantations. This is despite the fact that large-scale forestry plantations make up a substantial share of the global land rush and predictions that the demand for land for industrial forestry is likely to increase considerably in the next two decades (Lambin and Meyfroidt, 2011; Kröger, 2012). Forestry plantations are not only profitable due to their wood products but also as providers of carbon sequestration certificates that can be sold on the global market of greenhouse gas emission reductions. They are long-term, highly vulnerable investments, prone to fires and illegal harvesting. Therefore, we argue that forestry companies depend to a greater extent on the acceptance of the local population than other companies. Representatives of the examined companies emphasized that applying corporate social responsibility is a worthwhile strategy. This might be even more relevant for investors, such as the ones examined, who want to engage in the trade of emission certificates and need to observe international social and environmental standards.

Tanzania was chosen as case study country owing to its relatively abundant land availability (Deininger, 2011) and its laws recognising customary land rights (Alden Wily, 2012). While both analysed cases focus on forestry plantations in Tanzania, they differ in terms of local land availability, type of acquired land (individual or communal land holding) and offered compensation (in cash or in kind).

In the following, we first give a brief clarification of the conceptual and empirical approaches used in the study. After explaining the political and legal context of transnational land deals in Tanzania, we present the analysis of our case studies. The article closes with a discussion of the findings and concluding remarks regarding the land rush phenomenon.

\section{Conceptual and empirical approaches}

As an overall approach, we engage with a critical livelihoods perspective (Scoones, 2009; Geiser et al., 2011; de Haan, 2012), focusing on daily practices and experiences of poor people. With this, we bring in the perspective of those most affected by land deals. To unravel the powers that shape the land deal decisions, we combine access theory with a classical bargaining power perspective. The access theory of Ribot and Peluso (2003) helps one to understand how people gain, maintain and control access to certain natural resources. Access, "the ability to benefit from things" (Ribot and Peluso, 2003:153), is constituted by a bundle of strands of powers, also termed access mechanisms, that people or organizations hold or can draw upon. The presented power strands refer to both rights based and other structural and relational means of access, such as social identity (gender, ethnicity, etc.; see ibid., 170-171), and are often intertwined. The access theory helps us to analyse a broad range of factors that shape access and to understand why certain people are not included in decision-making. For the analysis of concrete negotiations of the land deals, we use elements of the bargaining power model developed by Yan and Grey (1994) based on classical bargaining and resource dependence perspectives (see also Inkpen and Beamish, 1997). The model looks at the relative bargaining power of parties in relationships formed on a voluntary basis. While it was developed to analyse international joint ventures (which is technically speaking not the case here), we argue it can nonetheless be applied in our case studies based on the long-term collaboration or at least acceptance that is needed between forestry companies and local people. The model distinguishes context-based elements of bargaining power such as the involved bargainers' alternatives to the deal, and resource-based components, e.g. land, money or labour, committed by the parties to the cooperative relationship. Bargainers committing crucial resources that are difficult for the other party to replace have high power in the negotiations, as they can use them as leverage. Thus, the bargaining perspective is useful in understanding the relevance of different elements of power in concrete bargaining situations.

The analysis is based on more than 150 qualitative interviews, mainly with local people from different backgrounds, and with key persons and state officials from the local, district, regional and national level. Group discussions were conducted with groups of men and women in three villages in each case study site. Several meetings were also held with staff of the company in case study B, while in case study A the contact to the company was limited to a few initial meetings and later refused. Fieldwork took place during 2010, 2011 and 2013.

\section{Transnational land deals in Tanzania: political and legal context}

Like many other developing countries in recent years, Tanzania has attracted a number of foreign investors interested in land. Tanzania has reportedly leased out an area of around 200000 to 1000000 hectares. While numerous investors headed for biofuel projects, many of these projects have been abandoned, mainly due to financial constraints. The focus of the more recent investment endeavours lies rather on food production. Further, there are few forestry projects of transnational companies, of which two have been chosen for this study (Sulle and Nelson, 2009; Locher and Sulle, 2013; Land Matrix, 2014).

The Tanzanian government has followed a policy of attracting foreign investors as part of its strategy for economic growth for around three decades and established the Tanzania Investment Centre (TIC) to encourage and facilitate foreign investments. National government officials (interviewed 
by Locher, 2010, 2011) argued that the rural areas in Tanzania could benefit from such investments in terms of labour opportunities, improved agricultural technologies and infrastructure. However, due to numerous land disputes, public pressure and deflating experiences with failing projects, in 2010 the government published guidelines which regulate and limit biofuel projects, and reportedly is in the process of establishing ceilings which would limit the size of future land deals for any agricultural purpose (Hultman et al., 2012; Kiishweko, 2012).

Tanzanian land law, regulated mainly by the Land Act and the Village Land Act of 1999, is relatively progressive in terms of respecting customary land rights (Alden Wily, 2012). Land in rural areas usually falls in the category of village land and is administered by the village council, on behalf of the village assembly, applying existing customary law. This is recognized by the state whether it is in written form or not. Village land may include land plots, which are given to individuals or households for permanent use and may also be inherited or sold (de facto ownership ${ }^{1}$ ) as well as common land to which all villagers have access to (e.g. forests), and barren land, which is considered as land reserve for future generations (URT, 1999a, b). Though the land acts have been enacted in 2001, they are still not enforced and practised everywhere (Pedersen, 2010) and the procedures regarding land deals are implemented only partially (Vermeulen and Cotula, 2010).

The current procedure for land acquisition is lengthy and onerous. Foreign investors cannot lease village land directly. Land deals are only possible if the land is transferred to the category general land, which is under the jurisdiction of the Ministry of Lands and Human Settlements Development (in short: Ministry of Lands). This process requires the village assembly's agreement ${ }^{2}$, documented by meeting minutes. Further, the involved parties have to agree on the compensation. Compensation should be based on market value, estimated by a government expert, and should be paid for land and unexhausted improvements, such as crops or trees. Finally, after several steps, the Ministry of Lands on behalf of the President enacts the land transfer.

\footnotetext{
${ }^{1}$ Despite the villagers' possibility to have de facto ownership of land, in the following, we use the term landholders, to accommodate the fact that legally, all land in Tanzania is public land vested in the president, who owns it on behalf of the whole nation (URT, 1999a).

${ }^{2}$ To be precise, for the transfer of areas larger than 250 hectares, the village assembly only gives a recommendation to the president, who makes the final decision; however, in the cases known to us this recommendation was never ignored in a way that an area larger than that agreed on by the village assembly would have been transferred. In some cases the opposite happened: the District Land Allocation Committee decreased the area to be transferred because it felt that otherwise the villagers would not have enough land left for their own (future) use.
}

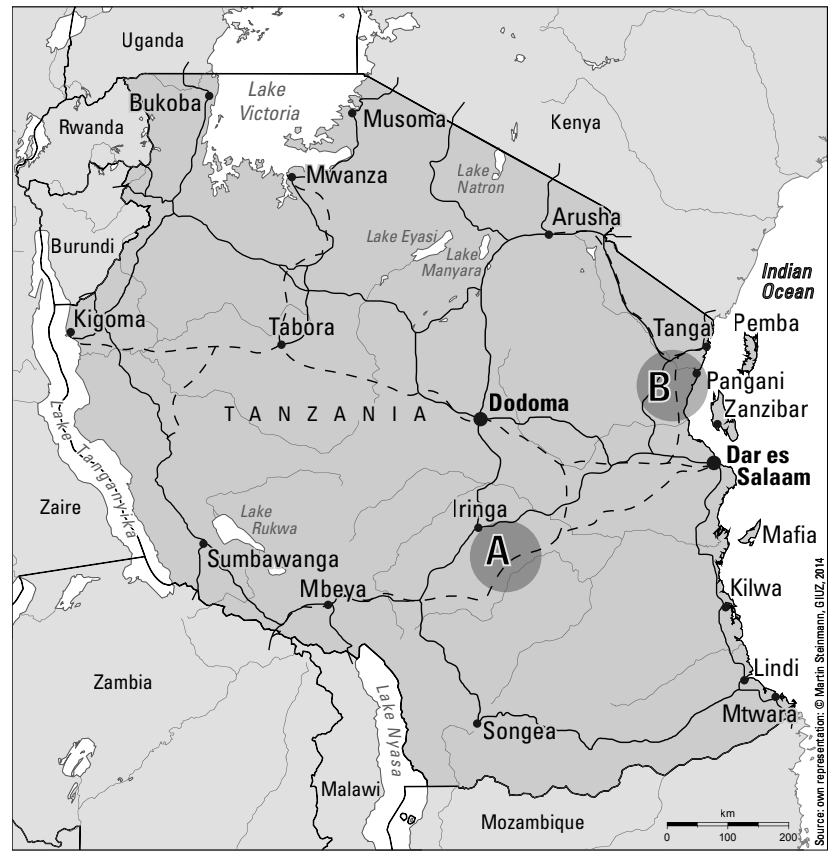

Figure 1. Map of Tanzania displaying the case study areas. A: New Forests Company (NFC) in Kilolo district, B: Tanga Forests Ltd $(\mathrm{TF})$ in Pangani district.

\section{Findings from the two case studies in Tanzania}

\subsection{The two investors and their forestry projects \\ 4.1.1 Case study A: the project of the New Forests Company in Kilolo district}

Kilolo is a hilly district in the Iringa region, in the Southern Highlands of Tanzania (cf. Fig. 1). It has favourable conditions for the permanent cultivation of several food crops. Many households also plant timber as savings, particularly on their less fertile or steep plots of land.

In 2006, a Member of Parliament from Kilolo introduced the New Forests Company (NFC) to his district. The UKbased NFC presents itself as a sustainable forestry enterprise, with plantations producing wooden feed materials in Uganda, Mozambique and Tanzania, and aiming to produce carbon certificates (NFC, 2014). Representatives of the NFC visited 12 villages to promote their investment. In some villages the company's request for land was declined because of a lack of land. Other villages welcomed the investor. By early 2013, the NFC had acquired 6300 hectares of land in seven villages (Table 1). The transferred land had mainly belonged to individual households. Some of the land had been permanently cultivated; other land lay fallow, mainly due to its remoteness. Landholders were compensated with cash. Further, the investor promised to support the local communities with infrastructure improvements, distribution of seedlings, and nursing training. In 2009, the company established a tree nursery and its first plantations of pine and eucalyptus 
Table 1. Share of village land provided to the investor in the Kilolo district (case study A) (based on figures obtained from the Kilolo district land officer in 2013).

\begin{tabular}{|c|c|c|c|c|}
\hline \multirow{2}{*}{$\begin{array}{l}\text { Village } \\
\text { Magome }\end{array}$} & \multirow{2}{*}{$\begin{array}{r}\begin{array}{r}\text { Total area of the } \\
\text { village (ha) }\end{array} \\
18636\end{array}$} & \multicolumn{2}{|c|}{ Area provided to NFC (ha) } & \multirow{2}{*}{$\begin{array}{r}\text { Share of village area } \\
\text { provided to NFC }\end{array}$} \\
\hline & & (one plot covering areas & 2295 & \\
\hline Kidabaga & 35007 & of all three villages) & & \\
\hline Idete & 1873 & & & \\
\hline Isele & 8272 & (one plot covering areas & 3852 & together $22.5 \%$ \\
\hline Kising'a & 8885 & of both villages) & & \\
\hline Ukwega & 8212 & & 122 & $1.5 \%$ \\
\hline Ipalamwa & 4275 & & 63 & $1.5 \%$ \\
\hline Total & 85160 & & 6332 & $7.4 \%$ \\
\hline
\end{tabular}

(personal communication by Locher with district land officer in 2013; Locher, 2011).

\subsubsection{Case study B: the project of Tanga Forests in Pangani district}

Pangani district is located on the northern coast of Tanzania (cf. Fig. 1). The local people practise small-scale subsistence farming, fishing and livestock keeping. Large areas are covered by bush land, partly used by pastoralists for grazing and by villagers for collecting firewood and grass that is used for weaving mats and other products.

The Norwegian company, Green Resources SA (GRAS) has been running large tree plantations in Iringa region since the 1990s. It produces and sells carbon certificates on the voluntary market (GRAS, 2013). In 2005, it established Tanga Forest Ltd (TF) as a subsidiary with the aim of expanding its plantations to Pangani and other districts in Tanga region. In 2006, TF started acquiring an area of around 7500 hectares in six villages in Pangani, mainly village reserve bush land. TF did not pay any compensation in cash, but constructed different infrastructural buildings in each village. It established a nursery and teak and eucalyptus plantations. In July 2012, GRAS closed down its subsidiary TF. The reasons given were the weak performance of the planted seedlings due to unsuitable soil and changing weather conditions as well as conflicts around land issues (personal communication by Locher with former Plantation Operations Manager in 2013).

\subsection{Local people's perceptions of the land deals and their consequences}

The case studies show that local people did not consider foreign investors as intruders and new colonists (as might be expected; see for example Via Campesina, 2012), but welcomed them, based on - at least partly justified - expectations of getting employment and highly needed infrastruc- ture or other benefits as compensation for their land. In principle, both types of compensation - in cash for individual land (in Kilolo) and in kind for communal land (in Pangani) - were appreciated. Individuals who received cash used it for varying short-term to more sustainable purposes based on their different livelihood assets and strategies. Many villagers were planning to use the money for their children's school fees. Others bought new land or invested in improved housing. Some households spent the money on consumption or health-related needs. Many people welcomed the compensation in terms of new infrastructure, particularly in Pangani (dispensary, village office, water tank, etc.) but also to a limited extent in Kilolo (maternity ward and school building improvement). They highlighted that the Tanzanian state did not have enough funds for providing such facilities. Interviewees further emphasized that there were no or not enough employment opportunities in their region and that "We have young people, they need to get a job". They therefore considered private investments necessary.

There are three crucial preconditions that determine the rather positive view of many local people. First, villagers strongly expect the investors to follow the proper procedure, to respect local land rights and provide the agreed compensation in time. Asked whether they would prefer foreign or domestic investors, interviewed villagers usually answered that this did not matter: "Important is that the company does the right thing, not the origin". This reflects the local people's strong dependence on the enforcement of the land law during the negotiations (discussed below).

Second, local people expect to continue their land based livelihood strategies. Thus, whenever possible, they only provided land to the investors that was of no current and direct use to them. Indeed, many people did not feel any direct change to their land-based livelihoods. One interviewee stated: "I cannot see anything bad. The land was not being used". However, there were cases in which villagers lost land against their will or were forced to sell due to hardship situations, and some of them reported decreased food security as 
a consequence of their reduced or lost possibility to produce food. A disappointed villager summarized these two crucial issues as follows: "The investor would be no problem, if they would follow the agreement. And if they would leave some land for us."

Third, local people wish to get additional labour opportunities to diversify their livelihood strategies. Both companies offered new income opportunities in the form of daily labour. However, the work load and conditions were considered very hard in case study A, and the salary low and often paid with delay in case study B. Mainly members of the poorest households accepted these insecure labour options and perceived them as a slight improvement for their livelihoods.

After having experienced tensions and conflicts related to omitted land rights or delayed compensation payments (discussed below) or when being deflated by unfavourable labour conditions, some affected people had a more nuanced perception or even turned against the companies, as the following two statements illustrate: "They have taken my land. I don't want to have any relation with them." "It is not a good deal, because the investor gets more than the villagers." However, a considerable part of the population continued seeing at least some benefits from the investments. Accordingly, many villagers were disappointed when TF closed down its activities.

\subsection{Strands of power shaping the land deal processes}

\subsubsection{Tanzanian land law in the context of complex land tenure situations}

Tanzanian law concerning land transfer, giving considerable decision power to the local population, has been followed in most of the analysed cases. Depending on the situation, entire villages and individuals participated in the decision-making process. Some also took the decision not to give land. Hence, in most of the cases the existent land rights were respected.

However, in some cases the local people have been excluded from the decision-making process. In other cases, they have been involved, but under unfavourable conditions. This happened particularly when complex land tenure situations prevailed. In Pangani, for example, one village had provided land to $\mathrm{TF}$ that belonged to two neighbouring villages. The conflict was brought to the Ministry of Lands, whose investigations confirmed the village boundaries, but only after the company had already established plantations on that land. The affected two villages could not take any decision in this regard, and had not received any compensation by 2012, when TF closed down. In another village in Kilolo, where village reserve land was sold, it turned out that part of the plot had been in use by people from the neighbouring village, based on longstanding local agreements. When the landholders realized that they had lost their land to the NFC, they appealed to their local leaders to claim it back. After around two years, the landholders were finally compensated, but not given back their land (Locher, 2011). An affected in- terviewee stated: "We don't have enough freedom to use our land rights", thus referring to other power strands besides the legal mechanism that shape the land deal processes.

\subsubsection{Government authorities' twofold influence in the land deal process}

Government authorities, be they politicians or civil servants, often act as intermediaries between investors and local populations. They are generally highly respected among the villagers due to their educational level and expert positions (cf. also Chachage and Baha, 2010). As Ribot and Peluso (2003:169) state: "Expert status also carries authority that may allow individuals to manipulate others' beliefs or the categories of resource access and use". Hence, first, government authorities play a key role in the decision-making for the land deals. During the promotional tours in Kilolo, for example, district leaders accompanied the company representatives. This entourage not only provided information about the procedures for the land deals but also enhanced the negotiated project's legitimacy and acceptance. A district land officer summarized the way how they approached the village assemblies as follows: "We told them: there is this company that wants to acquire land and you people have to provide your land". In both case study areas, some politicians from the local to the regional level played a double role. Investors hired them as land deal promoters; this was not always transparent to villagers. Being or having been well-known political representatives, these consultants had considerable influence on the villagers' decisions. A female interviewee in Kilolo stated the following: "These investors always come with district or regional leaders, they put pressure on us." Also in the above-presented case of conflicts around village boundaries in Pangani, a local politician employed by the company was involved.

Second, the influence of district officials and politicians is also crucial in the implementation of the legal process, including the clarification of complex land tenure situations and the settlement of the compensation. In both case studies, the clarification of land rights was not sufficiently carried out by the local leaders and district officials, leading to the above-mentioned conflicts. For compensation payment in Kilolo, the district valuer estimated the value of the land to be an average price of TSh $100000 /$ acre in 2008 (around EUR 135/hectare), which was paid during the first land transfers. However, the NFC representatives went on further promotional tours without district officers to request additional land. With the help of their hired consultants, they convinced a number of landowners to accept compensation clearly below market value, namely TSh 25 000/acre. In Pangani, the district officials made no estimation of the value of the land. Hence, it remains open whether the negotiated compensation was adequate or not.

In sum, by having highly respected politicians and sometimes also officers on their side, the investors benefit from 
their influence on local people's decision-making and their power to shape the implementation of the land deal process. This illustrates that "Access to authority is an important juncture in the web of powers" (Ribot and Peluso, 2003:170). Investors often have better access to authorities than local people, but access also differs among the local population.

\subsubsection{Legitimizing discourses}

The decision regarding land deals is influenced by the Tanzanian government's policy of encouraging land-based investments as part of a rural development strategy. Ribot and Peluso (2003:169) pointed out that "discourse and the ability to shape discursive terms deeply influence entire frameworks of resource access". By reproducing the national development discourse, government authorities at all levels provide legitimation for land deals. Investors draw upon this discourse to support their corporate social responsibility rhetoric during the promotional tours. In order to convince local people to provide land, both companies promoted a long-term, development-oriented "partnership" between themselves and the local population. The minutes of the general assemblies in several villages in Kilolo give some hints about the message the participants must have taken home from these promotional tours. They reveal a long list with a number of "purposes" of the NFC, which solely consist of benefits for the local people, such as general poverty reduction, protection of environment, employment opportunities and investments in infrastructure.

A counter discourse in this context, traceable in academic debates, is the concern about sufficient remaining land for future generations. However, only a few Tanzanian villagers and land officers referred to this discourse in specific landscarce situations, but never as fundamental argument against land deals.

\subsubsection{Unequal access to knowledge about land rights}

While investors have access to legal experts and can get support from the TIC in land rights issues, local communities have usually only very limited knowledge about the land law. It is the task of government officers to inform them about the legal procedures and their rights, but it seems that they did it to a varying and usually insufficient degree. Hence, in both case studies part of the individuals and villages gave away an important livelihood asset without being fully aware about the consequences. In Pangani, most of the villagers, including village leaders, were not aware that the land which was transferred to the category general land - to be provided to $\mathrm{TF}$ - was not in their hands anymore, but under the authority of the Ministry of Lands. They were convinced that they could withdraw it from the investor whenever they wanted. Another confusing matter was the unit of measurement. While in the rural areas acre is the common unit, investors and district staff used hectare - a considerable dif- ference of which not all villagers were aware. They also did not know that land should be compensated based on market values. In Kilolo, when problems arose in the case of village land that belonged to neighbouring villagers, most local people and their leaders did not have the necessary knowledge on how to reclaim their rights in time. Otherwise, they would probably not have lost the land against their will.

\subsubsection{Unequal resources and alternatives}

When it comes to negotiations between local landholders and investors, the investors' resource-based components of bargaining power consist of the offered compensation and labour opportunities, while the villagers' mainly commit their land and labour. Once land is transferred local people have no legal means to withdraw it from the investor. Hence, they can only contribute their labour to the proposed partnership, a resource that is easily replaceable, as shown in Kilolo, where labourers moved in from other areas. Unequal availability of alternatives to the deal further unbalance the bargaining power of the involved stakeholders: investors, at least in an initial stage, could go elsewhere to find suitable land and labourers for their endeavour, whereas many local people have restricted mobility and feel that the proposed investment is a unique opportunity to improve their livelihood situation. Also regarding work conditions, the lack of alternatives made labourers accept the conditions offered, as highlighted by an interviewee: "they [company's managers] know that even if they pay low salary you must work on their plantation because that's the only way you can get money". The companies thus profit from the local people's comparatively weak resource-based bargaining power and limited alternatives to the proposed deal.

\subsubsection{Local communities' potential resistance through threat of illegal actions}

In the conflictive cases where people's rights are contravened, ultimate means of resistance remain for them, i.e. the "weapons of the weak" (Scott, 1985, see also Wolford et al., 2013:195): they could harm the company by destroying their plantations. Although to our knowledge the villagers never openly threatened to employ this means, the atmosphere was very tense in the cases of denied land rights. It might have been fear of arson, combined with other reasons, which ultimately led the NFC to agree on an additional compensation payment in a conflictive case. Similar motives might have brought the TF to suspend their plantation activities in 2010 in one of the villages upon the demand of village leaders who suspected some inconsistency in the land deal process.

\subsubsection{Power differences within communities}

Local communities cannot be seen as homogenous with regard to their involvement in the decision-making process. 
They must be differentiated along different aspects of their social identity and individuals' assets such as education and financial resources, as illustrated in the following three examples.

In Pangani, it must be assumed that not all social groups had been represented equally in the village discussions and decisions. In particular, women and pastoralists were reported to participate less in village meetings, and could therefore not bring in their opinion. However, during interviews, no complaints were mentioned in this regard. In the conflictive case in Kilolo, most of the landholders have lost land against their will due to lack of awareness on how to (re)claim their rights in time. However, a knowledgeable businessman understood what was going on and managed to stop the district officials from surveying his plot for the land transfer (for details see Locher, 2011). Finally, households with a favourable combination of assets have had more freedom of decision on whether to transfer their land and under what conditions. In Kilolo, households in adverse economic conditions, be it due to a drought or personal reasons, rather accepted the deal, even when the compensation offered was low. In Pangani it became clear that the poorer households among the population that depended on labour income welcomed the investor on their village reserve land without further questioning, while members of better-off households rather raised issues such as the question of the quality of the offered compensation.

\section{Discussion and concluding remarks}

\subsection{Towards a better understanding of processes and consequences}

By analysing two forestry companies in Tanzania, we have deliberately chosen an investment sector and also a country with presumably more positive outcomes for local populations compared to land deals in other sectors and countries. It became obvious that even under these preconditions, the consequences for local people are ambivalent. Unequal power relations during the negotiations led to cases of violated land rights, inadequate compensation for the land and decreased food security in the worst cases. Further, the Tanzanian villagers involved have given up part of their reserve land for future generations, and have handed control of this land over to the national government and the investors, whose future actions are not fully predictable to them. The insights we gained go beyond the case studies. The focus on power in the negotiation process grasps power strands that play - of course with different weights - an important role in all land deals. It can be assumed that land deals under less favourable conditions lead to worse consequences for the local communities.

Besides this overall finding, our in-depth case studies have further contributed to a more differentiated picture of the global land rush in three aspects: first, in line with the liveli- hoods perspective, we have shown that local people have agency. Many deliberately decided for or against land deals. Under certain circumstances, namely (perceived) sufficient land availability and a fair land deal process, they welcome foreign investors. However, many villagers take their decisions in a weak position. Some were even passed over in the decision-making process.

Second, it is crucial to understand the detailed power strands at play and the different bargaining positions during the decision-making and negotiation processes. Such an analysis provides us indications for potential measures to better equilibrate the power positions. Our analysis revealed the following power strands: the land law as basis for rights-based means of access, access to influential government authorities, legitimizing discourses, varying knowledge on land rights and local people's potential resistance through illegal actions. In bargaining situations, the investors' favourable resources, based on financial means, and unequal availability of alternatives to the deal play a crucial role: as long as investors have rather unrestricted access to land in many countries, villagers' offered resources to the deals are comparatively easily replaceable for the investors. Moreover, as along as rural people experience only limited support in terms of infrastructure and income opportunities from elsewhere, they have hardly any alternatives to the proposed deals, which they often see as a chance to improve their livelihoods. These factors lead to villagers having rather weak bargaining power vis-à-vis the investors.

Third, the bargaining power vis-à-vis investors varies for different groups within local communities. Relevant factors are the economic situation, education, access to knowledge, gender, livelihood strategy and other aspects of social identity. Comparatively privileged households or individuals have a lower risk of agreeing to a land deal under unfavourable conditions and consequently suffering from adverse consequences. On the other hand, poor members of the communities might make use of new labour opportunities more often than wealthier people. Yet, due to the poor working conditions, we assume no substantial poverty reduction from these opportunities (see also Li, 2011). Hence, while a broad and in-depth impact analysis is still outstanding, our results indicate a tendency towards a potential fragmented development (see Rauch, this issue).

\subsection{What reactions against negative consequences of the global land rush?}

In absence of the possibility to halt the global land rush, efforts should first of all be made to channel land investments to areas with comparatively ample land availability. In practice, this is very delicate, as the division between land under use and unused land is not clear cut, and many (temporary or common) uses are difficult to identify (Borras Jr. and Franco, 2010). Further, areas with ample land and with limited land often co-exist at small scale. More importantly, 
the availability of unused land is generally decreasing. Also Africa, often considered as comparatively rich in unused land, has changed from "a continent of land abundance in the first half of the twentieth century to one of increasing land scarcity at its end" (Berry, 2002:639). Hence, the question of sufficient land for smallholders and future generations remains a tenuous issue. Many observers advocate a complete stop of large-scale land investments and increased support of the rural population instead (e.g. de Schutter, 2011; Li, 2011).

Second, as long as land deals continue, an attempt to reach more favourable outcomes requires a focus on the negotiations. In this context, the important role of the host governments must not be underestimated (Wolford et al., 2013; Peters, 2013). The first requirement is the general recognition of any land rights, including customary rights, by the national government (cf. Steimann and Geiser, 2012). When it comes to land deals, the involvement of (local) landholders as decision-makers is indispensable. This requires not only respective land laws and financial means to implement them but also political will and a respective attitude of government officials on all levels (Knight, 2010), in short, good governance. Then, a careful and impartial analysis of local land uses and rights, including those of pastoralists, women and other potentially vulnerable groups, should be a precondition for any land investment. Participatory land use planning at the village level, as foreseen in Tanzania, would be a potentially helpful tool in this regard, if it were implemented before any investors express their interest for the respective area. Further, the power positions during the negotiations must be better balanced in favour of the local populations, by providing them in-depth knowledge on their land rights and on potential risks of the land deals (e.g. through trainings conducted by NGOs beforehand or by lawyers that support the villagers during the process). Finally, the sometimes inconsiderate legitimation of land deals by the government based on development discourses needs to give way to a more critical picture of land investments that also sheds light on their multiple risks.

The following international initiatives address some of the above-mentioned concerns: the Principles for Responsible Agricultural Investment that Respects Rights, Livelihoods and Resources (FAO et al., 2010; in short: RAI principles) by the World Bank Group and three UN agencies address investors and host countries. The RAI principles are voluntary, and the scope of their effects is questioned (Borras Jr. and Franco, 2010; Locher et al., 2012). The Voluntary Guidelines on the Responsible Governance of Tenure of Land, Fisheries and Forests in the Context of National Food Security (FAO, 2012) have been developed in a participatory process involving FAO member countries, international organizations, the private sector and civil society. They address mainly potential host states. The guidelines provide a valuable basis, but need to be translated into concrete, effective instruments, adapted to the diverse national settings. However, good governance - the basis to implement any of these measures - remains an issue in most of the targeted countries.

Also some host countries have become more active in better regulating land deals. In Tanzania it seems that the government is currently gaining a more nuanced picture on land deals based on recent experiences with a large number of foreign investors. Thus, the land deals might lose their as of yet nearly unconditional legitimation by the government. The announced plans to limit the land size of individual deals and encourage out-grower models instead of largescale plantations point in this direction. There are also hints about a land for equity model to be encouraged in the future, where local people would not transfer their land to the investors, but allocate it to them for a certain period and gain shares of the companies' profit (Kiishweko, 2012; interview with TIC official by Locher, 2013). The possibility to withdraw land from investors would considerably strengthen the villagers' resource-based bargaining power. However, outcomes of such arrangements would still depend on many other power strands and would need to be scrutinized once implemented.

Finally, national policies of the investors' countries of origin need to be strengthened. An example is provided from Switzerland: a campaign of around 50 Swiss civil society organizations demands to make transnational land investments of Switzerland-based companies adhere to Swiss regulations (Recht ohne Grenzen, 2013).

\subsection{Outlook}

The global institutions influencing the global land rush - especially the financial market - are hardly comprehensible; thus scenarios about the future effects of this phenomenon on rural development in the global South remain partially speculative. There are hints about a slow down of foreign investments in some areas, e.g. in the biofuel sector of Tanzania (Hultman et al., 2012). A tendency away from land deals towards integration of smallholders in the global economy by contract-farming arrangements - as seems to be the case in Tanzania - is one scenario (Hall, 2011). However, the related developments and effects on rural populations must be again critically observed (see contribution by Franz in this issue).

As we have outlined, the effects of land deals differ considerably depending on the context and people's varying room for manoeuvre. Considerable positive outcomes are only to be expected under a bundle of conditions, which in practice are rarely met. The growing awareness of the phenomenon among academics and civil society organizations has led to a public outcry, which might eventually have effects on international and national policies and politics and companies' scope of action, but may also fade away unheard. On any account, one point is clear: the challenges for rural poor to cope with consequences of global actions at grassroots levels are enormous. Thus, the global land rush, as it is occurring so far, provides severe risks for the livelihoods of rural populations. 
Acknowledgements. This article is based on work conducted within the framework of the Swiss National Centre of Competence in Research North-South (NCCR North-South): Research Partnerships for Mitigating Syndromes of Global Change, and funded by the Swiss National Science Foundation (SNSF), the Swiss Agency for Development and Cooperation (SDC) and the University of Zurich. We would like to thank our interviewees for their readiness to participate, three field assistants for their valuable support, and Theo Rauch, Matthias Schmidt, Craig Hatcher, Rony Emmenegger, Stephan Hochleithner, Alice Kern, Sandra Evers, and two anonymous reviewers for their constructive feedbacks on the paper.

Edited by: B. Korf

Reviewed by: two anonymous referees

\section{References}

Alden Wily, L.: Looking back to see forward: The legal niceties of land theft in land rushes, J. Peasant. Stud., 39, 751-755, 2012.

Berry, S.: Debating the land question in Africa, Comp. Stud. Soc. Hist., 44, 638-668, 2002.

Borras Jr., S. and Franco, J. C.: From threat to opportunity? Problems with the idea of a "Code of Conduct" for land-grabbing, Yale Human Rights \& Development Law Journal, 13, 507-523, 2010.

Borras Jr., S. and Franco, J. C.: Global land grabbing and trajectories of agrarian change: A preliminary analysis, J. Agrar. Change, 12, 34-59, 2012.

Chachage, C. and Baha, B.: Accumulation by Land Dispossession and Labour Devaluation in Tanzania: The case of biofuel and forestry investments in Kilwa and Kilolo, Land Rights Research and Resources Institute (LARRRI/HAKIARDHI) and Oxfam, Dar es Salaam, 2010.

Cotula, L., Vermeulen, S., Leonard, R., and Keeley, J.: Land grab or development opportunity? Agricultural investment and international land deals in Africa, IIED, FAO, IFAD, London, Rome, available at: http://pubs.iied.org/12561IIED.html?k=vermeulen (last access: 13 January 2014), 2009.

de Haan, L.: The livelihoods approach: a critical exploration, Erdkunde, 66, 345-357, doi:10.3112/erdkunde.2012.04.05, 2012.

de Schutter, O.: How not to think of land-grabbing: three critiques of large-scale investments in farmland, J. Peasant Stud., 38, 249279,2011

Deininger, K.: Challenges posed by the new wave of farmland investment, J. Peasant Stud., 38, 217-247, 2011.

Edelman, M., Oya, C., and Borras Jr., S. M.: Global land grabs: historical processes, theoretical and methodologcial implications and current trajectories, Third World Q, 34, 1517-1531, 2013.

Evers, S. J. T. M., Seagle, C., and Krijtenburg, F. (Eds.): Africa for sale? Positioning the state, land and society in foreign large-scale land acquisitions in Africa, Brill Academic Publishers, Leiden, 2013.

Food and Agriculture Organization (FAO): Voluntary Guidelines on the Responsible Governance of Tenure of Land, Fisheries and Forests in the Context of National Food Security (11 May 2012), available at: www.fao.org/nr/tenure/voluntary-guidelines/en (last access: 13 January 2014), 2012.
Food and Agriculture Organization (FAO), International Fund for Agricultural Development (IFAD), United Nations Conference on Trade and Development (UNCTAD): Principles for Responsible Agricultural Investment that Respects Rights, Livelihoods and Resources: Extended version, 25 January 2010, available at: www.responsibleagroinvestment.org/rai/node/256 (last access: 13 January 2014), 2010.

Geiser, U., Müller-Böker, U., Ramakumar, R., Shahbaz, B., Steimann, B., and Thieme, S.: Towards an analytical livelihoods perspective in critical development research, in: Perspectives of the Swiss National Centre of Competence in Research NorthSouth, edited by: Hurni, H. and Wiesmann, U., Geographica Bernensia, Bern, 6, 257-271, 2011.

Green Resources (GRAS): www.greenresources.no/, last access: 2 December 2013.

Hall, R.: Land grabbing in Southern Africa: the many faces of the investor rush, Review of African Political Economy, 38, 193214, 2011.

Hultman, N. E., Sulle, E. B., Ramig, C. W., and Sykora-Bodie, S.: Biofuels Investments in Tanzania: Policy Options for Sustainable Business Models, J. Environ. Develop., 21, 339-361, 2012.

Inkpen, A. and Beamish, P. W.: Knowledge, bargaining power, and the instability of international joint ventures, Acad. Manag. Rev., 22, 177-202, 1997.

Kiishweko, O.: Curbing Tanzania's "Land Grabbing Race", Inter Press Service News Agency, available at: www.ipsnews.net/ 2012/12/curbing-tanzanias-land-grabbing-race/ (last access: 13 January 2014), 2012.

Knight, R. S.: Statutory Recognition of Customary Land Rights in Africa: An Investigation into Best Practices for Lawmaking and Implementation, FAO Legislative Study 105, Food and Agriculture Organization of the United Nations, Rome, 2010.

Kröger, M.: Global tree plantation expansion: a review, ICAS Review Paper Series No. 3, Initiatives in Critical Agrarian Studies, International Institute of Social Studies, The Hague, available at: www.iss.nl/fileadmin/ASSETS/iss/Documents/ Academic_publications/Markus_Kroeger_ICAS_WP_3_EN.pdf (last access: 13 January 2014), 2012.

Lambin, E. F. and Meyfroidt, P.: Global land use change, economic globalization, and the looming land scarcity, P. Natl. Acad. Sci., 108, 3465-3472, 2011.

Land Matrix: http://landmatrix.org/, last access: 9 January 2014.

Li, T.: Centering Labor in the Land Grab Debate, J. Peasant Stud., 38, 281-298, 2011.

Locher, M.: "How come others are selling our land?" - Customary Land Rights, Rural Livelihoods and Foreign Land Acquisition in the Case of a UK-based Forestry Company in Tanzania, International Conference on Global Land Grabbing, Brighton, UK, 6-8 April 2011.

Locher, M. and Sulle, E.: Foreign land deals in Tanzania: an update and a critical view on the challenges of data (re)production, LDPI Working Paper 31, available at: www.plaas.org.za/sites/default/ files/publications-pdf/LDPI31Locher\%26Sulle.pdf (last access: 13 January 2014), 2013.

Locher, M., Steimann, B., and Upreti, B.: Land grabbing, investment principles and plural legal orders of land use, Journal of Legal Pluralism, 65, 31-63, 2012.

New Forests Company (NFC): www.newforests.net, last access: 13 January 2014. 
Pedersen, R. H.: Tanzania's Land Law Reform: the Implementation Challenge, DIIS Working Paper 37, Danish Institute for International Studies, Copenhagen, 2010.

Peters, P. E.: Conflicts over land and threats to customary tenure in Africa, Afr Affairs, 1-20, 2013.

Recht ohne Grenzen: www.rechtohnegrenzen.ch/de/kampagne, last access: 3 December 2013.

Ribot, J. and Peluso, N.: A Theory of Access, Rural Sociol, 68, 153-81, 2003.

Scoones, I.: Livelihoods perspectives and rural development, J. Peasant Stud., 36, 171-196, 2009.

Scott, J. C.: Weapons of the weak. Everyday forms of peasant resistance, Yale Univ. Press, New Haven, London, 1985.

Smalley, R. and Corbera, E.: Large-scale land deals from the inside out: findings from Kenya's Tana Delta, J. Peasant Stud., 39, 1039-1075, 2012.

Steimann, B. and Geiser, U.: Ensuring Land Rights Benefit the Poor, Evidence for Policy Series, Global Edition, No. 7, NCCR NorthSouth, Bern, available at: www.zora.uzh.ch/66552 (last access: 13 January 2014), 2012.
Sulle, E. and Nelson, F.: Biofuels, land access and rural livelihoods in Tanzania, IIED, London, 2009.

United Republic of Tanzania (URT): Land Act (No. 4 of 1999), URT, Dar es Salaam, 1999a.

United Republic of Tanzania (URT): Village Land Act (No. 5 of 1999), URT, Dar es Salaam, 1999b.

Vermeulen, S. and Cotula, L.: Over the heads of local people: consultation, consent, and recompense in large-scale land deals for biofuels projects in Africa, J. Peasant Stud., 37, 899-916, 2010.

Via Campesina: Tanzania: Farmers want the government to stop land grabbing, available at: http://viacampesina.org/en/index.php/actions-and-eventsmainmenu-26/17-april-day-of-peasants-struggle-mainmenu-33 (last access: 13 January 2014), 18 April 2012.

Wolford, W., Borras Jr., S., Hall, R., Scoones, I., and White, B.: Governing Global Land Deals: The Role of the State in the Rush for Land, Dev. Change, 44, 189-210, 2013.

Yan, A. and Gray, B.: Bargaining power, management control, and performance in United States-China Joint Ventures: a comparative case study, Acad. Manag. J., 37, 1478-1517, 1994. 